\title{
National security: green production to ensure quality of labor force
}

\author{
Ekaterina Gayduk ${ }^{3,{ }^{*}}$,Eleonora Matyugina ${ }^{1,3}$, Olga Pogharnitskaya ${ }^{2,3}$, and Lyudmila \\ Bolsunovskaya $^{2}$ \\ ${ }^{1}$ National Research Tomsk State University, 36, Lenina avenue, 634050, Tomsk, Russia \\ ${ }^{2}$ National Research Tomsk Polytechnic University, 30, Lenina avenue, 634050, Tomsk, Russia \\ ${ }^{3}$ Tomsk State University of Control Systems and Radioelectronics, 40, Lenina avenue, 634050, \\ Tomsk, Russia
}

\begin{abstract}
The purpose of the study is to the investigation of the characteristics of the green production in the context of ensuring national security. The authors used such research methods as analysis and synthesis, generalization, induction, a systematic approach. This paper proves the dual nature of the labor force involved in the formation of forward movement of the national economy, the state parameters of which are double as estimation criterion of the effectiveness of measures implemented. The combination of national security and the inseparable manifestation of the labor force status in this system are disclosed in the characteristics of the first as a whole system that allowed us to prove the mutually supportive component of national security. We highlighted the impact of production on health and employability directly during the production process and indirectly through the deterioration of habitat characteristics, as were the findings that had been supported by countryspecific morbidity statistics, with a focus on regional specifics. The intensity of the integration the environmental component into production, which forms the ecological and ecologized types of the latter, supplemented by synchronization of implemented measures with the production process (in-process measures, follow-up measures, forestall measures). The paper also reflects the significance of compliance with proactive measures that complement the fulfillment of mandatory requirements ensuring the legitimacy of management and indicates the need of taking into account the specific characteristics of the territory of presence. The study based on evidence provided under the legislative and regulatory legal acts of the Russian Federation and materials on activities of Russian companies.
\end{abstract}

\section{Introduction}

The high developmental dynamism of the production resources, recognized as the imputed characteristic of modern management, determines the mobility and complexity of forecasting the parameters of the external and internal environments that actualizes the

\footnotetext{
*Corresponding author: gayduk-fdo@mail.ru
} 
issues of ensuring the sustainability of the national economy, by placing priority on issues of maintaining state security. The latter is understood as "a state of security against internal and external threats, which ensures the decent quality of life and standards of living for the population, sovereignty, independence, state and territorial integrity, sustainable socioeconomic development" [1].

Achieving, and, moreover, maintaining such a state for a long time, would imply the use and compilation of a significant amount of resources, in which a special place is occupied by labor ones.

Their uniqueness is due to the fact that, on the one hand, labor resources are the driving force of the progressive movement of national production, subject to its wear and tear. On the other hand, the quality and standard of living of the population have an estimated status of measures implemented by the state (the list of safety indicators includes GDP per capita; $\mathrm{R} / \mathrm{P}$; inflation rate; unemployment rate; share of science, technology, education, and culture expenditures in GDP; life expectancy, etc. [1]).

\section{Materials and Method}

The methodology for the research included: systematic, deductive and comparative methods. For the formulation of theoretical postulates used law and regulation of the Russian Federation, and research materials. The study contains extensive factual material presented by rating data, official statistics, and reports of Russian companies.

\section{Results}

The labor forces have been given the status of a central component of the security system, the interests of which the organization of human life is subordinate to, is reflected in the properties of the named system.

In a case in point:

- integrity, which believes that each element contributes to the realization of the global goal - the welfare of the population. Thus, the Food Security Strategy states that food security is one of the leading directions of ensuring national security, a factor in maintaining statehood and sovereignty, a condition for improving the quality of life;

The Strategy of Demographic Security is aimed at increasing the life expectancy of the population, reducing mortality, increasing fertility, regulating internal and external migration, maintaining and strengthening health, etc.The implementation of the Economic Security Strategy related to the counteracting challenges and threats in the economic sphere, preventing crises in the resource-based, manufacturing, scientific, technological and financial spheres, as well as preventing the decline in the quality of life of the population [2-4].

- emergence, which ensures, together with integrity, the integrative properties of the system, by means of maximum outreach spheres that are specific in content and instruments used (for example, a significant difference in the organization of the security forces, social, economic and other spheres while maintaining their goal orientation);

- organization, which serves as the basis for positioning the totality of components of national security, the orderliness of which guarantees the state's focusing on ensuring the welfare of citizens.

So, the quality of the living environment, as a factor in maintaining the health and working ability of the population, involves the construction of environmental and economic interactions of economic entities, reflected in the cleaner production. 
It is worth mentioning the presence in indicator series of national security such a criterion as the share of the territory of the Russian Federation that does not meet environmental standards [1];

- hierarchy, contributing to the formation of level security - noting the complex hierarchical structure of the national security system.

For example, the implementation of the State "Health" programme [5] involves conducting epidemiological studies, developing the infrastructure of medical institutions, implementing information campaigns, monitoring the compliance of tobacco and alcohol products with quality standards, hygienic standards, and GOST;

- stability, reliability, adaptability - the combination of these system properties is unified due to the fact that they simultaneously act as evaluation criteria for the efficiency of the system itself.

So, to level out the natural population decline (259.6 thousand people in 2019 according to the Federal State Statistics Service [6]), which is a threat to the stability of the state, it is planned to implement a number of measures: increase the expected duration of a healthy life (up to 67 years), increase the total birth rates of up to 1.7, the implementation of social measures to support families, etc.

Recognizing the special status of labor forces, it should be noted that they simultaneously acquired the roles of an executor and a recipient of benefits; initiator of the creation of the system and the recipient.

Their state parameters are the focus of a whole spectrum of activities, instantly bearing the consequences of changes in any component of security.

This allows us to consider various aspects of human settlements as a kind of indicator of the effectiveness of measure implementation to ensure the protection of national interests, as illustrated by the fact that one of the goals of the National Security Strategy is creating conditions for full development of the human personality, "neighboring" with such landmarks as the transition of the economy to a new level of technological development, Russia's entry into the number of countries that are leaders in terms of GDP and successful opposition to the influence of internal and external threats (paragraph 55) [1]).

A permanent complication of the production, being a condition of competitiveness, places high demands on the professionalism, experience, and education of company personnel; forms requirements not only for continuous improvement of existing competencies but also for the development of new ones. As a result, labor stress increases, chronic fatigue syndrome forms, etc., exacerbated by environmental problems. The company's staff is "between two fires" - on the one hand, the production process (harmful production factors) directly affects their health and ability to work, and on the other, the worsening environmental situation provokes an increase in the incidence of disease.

There is a significant span of points rating of the share of technogenic factors in the formation of population health from 15 to $57 \%$ [7-9].

All-Russian morbidity trends by some categories of disease can be found in table1.

Table 1. Dynamics of the Main Disease Categiries at the population level (per 1000 people) [10].

\begin{tabular}{|l|c|c|c|c|c|}
\hline \multicolumn{1}{|c|}{ Disease Category } & $\mathbf{2 0 0 6}$ & $\mathbf{2 0 1 1}$ & $\mathbf{2 0 1 6}$ & $\mathbf{2 0 1 7}$ & $\mathbf{2 0 1 8}$ \\
\hline $\begin{array}{l}\text { endocrine system diseases, nutritional disorders and } \\
\text { metabolic diseases }\end{array}$ & 11.7 & 10.3 & 13.9 & 14.0 & 13.1 \\
\hline diseases of the nervous system & 16.2 & 16.5 & 15.2 & 15.0 & 14.8 \\
\hline circulatory diseases & 26.5 & 26.6 & 31.7 & 32.1 & 32.6 \\
\hline diseases of the respiratory system & 296.0 & 338.8 & 351.6 & 353.5 & 369.8 \\
\hline diseases of the digestive system & 35.1 & 33.3 & 35.6 & 34.0 & 33.1 \\
\hline diseases of the skin and subcutaneous tissue & 50.6 & 47.5 & 42.6 & 41.0 & 40.3 \\
\hline diseases of the genitourinary system of & 48.7 & 49.3 & 45.6 & 44.8 & 44.8 \\
\hline $\begin{array}{l}\text { injury, poisoning and certain other consequences of } \\
\text { external causes }\end{array}$ & 89.2 & 92.8 & 89.1 & 88.2 & 89.0 \\
\hline
\end{tabular}


Almost every Russian region has a "weak point". So, the environmental problem of the Kemerovo region is an air pollution mainly by enterprises of the coal, fuel and chemical industries, metallurgy, and energy.

The incidence of bronchopulmonary pathology of the urban population of the Far East is 1.3 times higher than that of the rural population, which is explained by a higher population density, and, consequently, a wider spread of airborne infections, exacerbated by environmental pollution.

An analysis of the morbidity of the population in Novgorod region showed that respiratory diseases $(23.7 \%)$ took first place [11-13].

According to the data of the National [14] environmental rating (autumn 2019), Moscow; Nizhny Novgorod; Orenburg; Omsk region; Sverdlovsk; Chelyabinsk region; Irkutsk region; Krasnoyarsk and Transbaikal Territories; The Republic of Sakha (Yakutia) are among the most polluted regions of Russia.

Besides external impact, manifested in the deterioration of the environmental situation, production also has an impact on the employee directly in the process of his labor activity.

These are harmful production factors that influence workers for example, physical factors (increased or decreased air temperature, high humidity, increased noise levels, vibration, dust and gas contamination, etc.); chemical (general toxical, sensitizing, carcinogenic, etc.) ), biological (bacteria, viruses, etc.)).

They are complemented by high tension and labor intensity - people of active age (from 35 to 45 years old [15]) are most susceptible to destructive stress.

The insistence on preserving the ability of personnel to perform the duties assigned to them in the conditions of dynamically complicating production, increasing technogenic pressure on the environment requires the inclusion of compensatory mechanisms in the production process, the content of which corresponds to the forms of the impact of the latter on health and ability to work. This allows us to certify measures for the cleaner production as an instrument for the stable functioning of national production.

The specifics of embedding the environmental component in production activities determines the type of production: the ecological one, which implies the prevalence of the environmental factor (for example, the interaction of Eco Technologies and SIBUR to create closed-loop economy technologies) and ecologized, operating on the principles of reducing the negative impact on the environment (Gazprom Group's activities as part of a program to increase environmental friendliness of transport [16]).

The antagonism of economic and environmental spheres, manifested, for example, in the absence of subjects' interest in compensating for environmental damage, requires the introduction of environmental standards by the state and monitoring of their implementation as a condition of economic legitimacy.

However, strong regulation provokes the desire of a number of business entities to "move away" from them or to "ritual" compliance. Initiative reduction and/or compensation of the effects of technogenic pressure on the environment requires the introduction of additional incentives - for example, the status of a stakeholder in the territory of presence, the formation of the image of a socially oriented company (see Table 2). 
Table 2. Examples of measures implemented by companies [17, 16, 18, 19, 20].

\begin{tabular}{|c|c|}
\hline Company & Measures Implemented \\
\hline PJSC Gazprom & $\begin{array}{l}\text { In } 2018 \text {, more than } 800 \text { activities were completed by the company: more } \\
\text { than } 15 \text { thousand trees and shrubs were planted; more than } 150 \text { tons of } \\
\text { garbage were collected; } 62 \text { thousand fry and juvenile fish were released } \\
\text { into water bodies. } \\
\text { In } 2018,49 \text { plants and facilities for wastewater treatment with a capacity } \\
\text { of } 52.31 \text { thousand cubic meters per day took into use; } \\
3 \text { recirculating water systems with a capacity of } 0.27 \text { thousand cubic } \\
\text { meters. per day; } 18 \text { waste treatment and disposal facilities with a } \\
\text { capacity of } 6.81 \text { thousand tons / year; landfill for utilization, } \\
\text { neutralization and disposal of waste with a capacity of } 17.02 \text { thousand } \\
\text { tons / year }\end{array}$ \\
\hline PJSC Gazprom Neft & $\begin{array}{l}\text { The company interacts with indigenous peoples, taking into account } \\
\text { their interests in the formation of each field development project. } \\
\text { PJSC Gazprom and PJSC Gazprom Neft on the Yamal Peninsula have } \\
\text { tested methods based on the use of new biological products that contain } \\
\text { microorganisms - hydrocarbon destructors that allow biological soil } \\
\text { clean-up at low temperatures }\end{array}$ \\
\hline $\begin{array}{l}\text { OJSC MMC Norilsk } \\
\text { Nickel }\end{array}$ & $\begin{array}{l}\text { In 2018, the environmental forum "Environmental Protection and } \\
\text { Sustainable Development of the Northern Territories" was held. } \\
\text { Much attention is paid to environmental monitoring and site } \\
\text { rehabilitation in the territories of presence - on the Kola Peninsula, the } \\
\text { company cooperates with the Lapland Nature Reserve, and in the } \\
\text { Pechenga District with the Pasvik Nature Reserve. }\end{array}$ \\
\hline $\begin{array}{l}\text { Novolipetsk } \\
\text { Metallurgical Plant } \\
\text { (NLMP) }\end{array}$ & $\begin{array}{l}\text { NLMP Group's investments in the environmental sector amounted to } \\
\text { about } 29 \text { billion rubles for the period of } 2013-2017 \text {. This allowed with } \\
\text { output rising to } 11 \% \text { reducing specific emissions by } 6 \% \text {, per-capita } \\
\text { water consumption by } 16 \% \text {, waste generation by } 15 \%\end{array}$ \\
\hline PJSC Pig & $\begin{array}{l}\text { Over the period of 2013-2018, the generation of industrial effluents and } \\
\text { atmospheric emissions were decreased on average twice }\end{array}$ \\
\hline
\end{tabular}

\section{Discussion}

The data presented reflect a wide range of measures implemented - affecting not only the production sector but also cooperation with other entities, which allows us to talk about the diffusion of the ecological component into the system of interactions of the subject. The greening of production involves not only the fullest possible use of the production potential in the aspect of efficient use of environmental objects (for example, technology for the reuse of waste, optimal production planning, etc.) but control over their use, improvement and a kind of "care" for it condition.

The distribution of countervailing measures in relation to production allows us to distinguish the following groups of measures to green production:

- accompanying, associated with the observance of existing rules, norms and standards for environmental protection;

- follow-up measures aimed at compensating for the consequences of the negative impact,

- forestall measures forming the basis for the development of greening, carried out as part of investing in the improvement of production. 


\section{Conclusions}

The expected result of the green production is considered a new, improved type of production that reduces environmental risks and prevents environmental pollution and negative consequences.

Obviously, the achievement of such a result is the fulfillment of one of the tasks of national security, manifested in the form of ensuring protection in the field of ecology, production and working conditions while achieving high quality and living standards of the population.

\section{References}

1. Strategiya nacional'noj bezopasnosti Rossijskoj Federacii : ukaz Prezidenta RF № 683 (2015)

2. http://www.consultant.ru/document/cons_doc_LAW_191669/

3. http://www.consultant.ru/document/cons_doc_LAW_96953/

4. https://rosmintrud.ru/ministry/programms/6

5. http://www.consultant.ru/document/cons_doc_LAW_216629/

6. http://national.invur.ru/index.php?id=116

7. https://gks.ru/storage/mediabank/osn-10-2019.pdf

8. Y.P. Lisicin, N.V. Polunina, Obshchestvennoe zdorov'e i zdravoohranenie (Medicina, Moscow, 2002)

9. A.A. Baranov, A.G. Il'in, Vestnik RAMN 6, 12-18 (2011)

10. G.G. Onishchenko, Gigiena i sanitariya 6, 3-4 (2003)

11. Rossiya v cifrah 2018: Krat.stat.sb. (Rosstat, Moscow,2018)

12. L.S. Horoshilova, L.M. Tabakaeva, I.V. Trofimova, Vestnik KemGU 2(42), 150-154 (2010) doi: 10.21603/2078-8975

13. S.V. Senotrusova, Ekologiya cheloveka 9, 15-18 (2005)

14. M.A. Yuzbekov, A.K. Yuzbekov, Vestnik RUDN. Seriya: Ekonomika 1, 49-55 (2012)

15. https://greenpatrol.ru/ru/novosti/nacionalnyy-ekologicheskiy-reyting-subektovrossiyskoy-federacii-po-itogam-oseni-2019-goda

16. A.A. Mihajlov, A.E. Kuz'minskij, T.S. Smirnova, Moskovskij ekonomicheskij zhurnal 8, 546-554 (2019) doi: 10.24411/2413-046X-2019-18017

17. https://www.gazprom.ru/f/posts/72/692465/gazprom-environmental-report-2018-ru.pdf

18. https://www.gazprom.ru/about/subsidiaries/news/2018/august/article451032/

19. http://ecomurmanskforum.ru/

20. http://xn--j1abdc.xn--p1ai/upload/iblock/c50/nlmk_eco_rus_2505_web.pdf

21. https://krata.ru/index.php/ru/o-kompanii/novosti/432-v-2018-g-pigment-prodolzhaetuspeshno-vesti-rabotu-po-ekologicheskoj-modernizatsii-proizvodstva-na-predpriyatii 